\title{
Qualitative Analysis on the Academic Work
}

\author{
Fethi Bin Muhammad Belgacem' \\ Dionéia Motta Monte-Serrat" \\ Carlo Cattani"II \\ Daniela Monte-Serrat Cabella ${ }^{\mathrm{I}}$
}

ThePublic Authority for AppliedEducation and Training(PAEET),AlArdhiya-Kwait "Universidade de Ribeirão Preto (UNAERP), Ribeirão Preto/SP - Brazil "ITuscia University (UNITUS), Viterbo/VT - Italy "vniversidade de São Paulo (USP), São Paulo/SP - Brazil

\begin{abstract}
Qualitative Analysis on the Academic Work. This article makes a qualitative analysis of what constitutes the academic work in its overlapping elements and processes. There is a joint analysis of theory and facts based on discourse analysis theory to observe intrinsic aspects that put creativity as an essential product of academic work, and extrinsic aspects necessary to establish trust and dignity as necessary assumptions to achieve its goal. We hope this approach become an available tool to protect creativity against abuses of power and to show how one builds a balanced academic work within an ethical dimension, preventing the construction of a fallacious product.

Keywords: Academic Work. Qualitative Analysis. Ethics. Creativity. Intellectual Property.

RESUMO - Análise Qualitativa do Trabalho Acadêmico. Este artigo faz uma análise qualitativa do que caracteriza o trabalho acadêmico em seus processos e elementos que se sobrepõem. Análise e teoria caminham juntas com base na teoria da Análise do Discurso para observar aspectos intrínsecos, que colocam a criatividade como produto essencial do trabalho acadêmico, e aspectos extrínsecos, necessários ao estabelecimento da confiança e da dignidade a fim de que esse trabalho alcance seus objetivos. Espera-se que essa abordagem se torne uma ferramenta útil para proteger a criatividade contra o abuso de poder e para mostrar como se constrói um trabalho científico equilibrado e ético, prevenindo a construção de um produto falacioso.

Palavras-chave: Trabalho Acadêmico. Análise Qualitativa. Ética. Criatividade. Propriedade Intelectual.
\end{abstract}

Educação \& Realidade, Porto Alegre, v. 44, n. 4, e90059, 2019. 
Qualitative Analysis on the Academic Work

\section{Introduction}

In this article we embrace a qualitative research point of view to make an analysis of what constitutes the academic work in its essence. The interpretation of its ethical dimension involves a logic of a heterogeneous context that connot be deprived. In order to get out of the paralyzing approach of quantities and to see the scientific work qualitatively understanding its overlapping elements and processes, we use the methodology originated in the works of Michel Pêcheux (1988) and Michel Foucault (European Parleament, 2002[1969]).

The ethical dimension on intellectual production forms a basis which recognizes an inherent dignity and trust into very subtle rights that are not widely spoken but have a relevant role in it. In this regard an discursive analysis approach is taken in various aspects of the academic work: i) the regulations and laws that characterize the academic life and copyright; ii) the aptitude and the meaning of trust and dignity in the psychological and ethical aspect of the development of scientific research activity; iii) a concrete example where it is analyzed the mentor in the interaction with his pupil, which has the role of serving to establish a new concept in the academy regarding to the breach of trust: The Reverse Shameful Stockholm Syndrome, RS3.

The qualitative perspective gives us a way to better understand the scientific work in its sense of the whole; this is a way of exploring how its elements constitute relational ties and identify key points that have repercussions on its content. The administrative context, for example, and the task of teaching itself, both are related tothe elements trust and dignity in a social context so that, in a joint work, the common goals of researchers are achieved. Confidence and security as the result of complex processes provide a suitable environment for the establishment of creativity in the research. On the other hand, circumstances that make the political context, vanity or financial interests prevail drive away this precious product and turn academic work into a fallacy or rather saying: the academic context by itself does not guarantee that the result is actually considered an academic work.

The interaction and interdependence between professor, student and academic environment are not enough. Together with the professional relationship comes the regulation of their interdependence by the State. They are subjected to power strategies in order to be structured, managed and monitored. Another point that should be considered is the fact that the scientific work is connected to a creative and constructive process that involves, beyond professor-student, the participation of officers of a committee in a decision over others, all those who have endorsed, supported or helped to achieve the final research result. This is a work that cannot ignore previous documents and evidences; it cannot leave aside the customs and laws academic and moral. Attitudes of violation of these assumptions violate human rights, imply criminal responsibility, and, finally, suffocate creativity, which would be the greatest product of the Academy. 
In a few words, this article shows how one builds the academic work and what are some of the elements that interferes in its balance, producing or preventing the construction of a creative product. There is interdependence between regulations, rights and ethical conduct on its constructive process. It will be shown that the break of this interdependence can be seen sometimes as the inverse of the Stockholm Syndrome.

\section{Qualitative Approach}

The qualitative analysis is based on the reasoning developed by Pêcheux (1988) and Foucault (European Parleament, 2002[1969]) so it can be observed not only what is apparent but also the underlying cause of certain facts. This is why analysis and theory go together in this article (Monte-Serrat, 2013, p 47).

It is not intended to develop a content analysis on the elements that compose the work in the academy, but to establish relations of dependence between these elements and the context of scientific research, simultaneously analyzing them as the conditions of production of what characterizes it. We understand that content analysis does not let us get out of a place previously set by ideology, with its goals and rules to be fulfilled. The practice of discursive analysis allows us to escape from this circularity to try to overcome vices that withdraw from the academic work its essence of truth, dignity and creativity.

The studies of the discourses of scholars and laws through discourse analysis are able to unveil a sense that emerges from the relations influenced by the ideology existing in the socio-historical process. There are ideological positions defined as a complex set of attitudes and representations that are neither individual nor universal but relate more or less directly to a conflict and determine what can and should be said (Monte-Serrat, 2013, p. 69). The content of the words employed by professionals in the academic context and what the laws and regulations say are in the background in this study. Our analysis focuses on a determination given in advance to the place that the academic and the student should occupy in social relations.

The discourse of what is academic work is a representation of the reality constructed by knowledge and governs positioning what can be done and what cannot. We examine the power influence on some aspects of the academic processes imposing some categories of thinking taken as truths that denies ethical principles; putting in check what is true in academic work and what is regulation; making us reflect on whether what the scientist produces is something creative or a reworked result of some previous research, only to meet quantitative targets.

\section{Regulatory Essence in the Research Activity}

The discourse of the law has the function of covering, under a pavilion, different and sometimes unconfessable goods. Discourse Analy- 
Qualitative Analysis on the Academic Work

sis enables a scientific study of the laws without reproducing this reality. Based on the conditions of the socio-historical context in which the science of law appears, one can arrive at an idealism of juridical explanations that disconnects from reality (Monte-Serrat, 2013).

Law establishes a right to a minimum of security to develop researches and there would be no difference in the assessment of who should have more security or less security in his rights. All the researchers are supposed to be equal before the law and to have the same rights. But we can find, in some circumstances, false and unjust political decisions inside of the Academy, justified by fallacious arguments, that give the status of something legal to incomplete data and statements that simulate veracity, causing disorders and injustice in the academic environment, that do not die by statute of limitations or by the death of their perpetrators. Dealing with them and with falsehood can lead to a domino effect that needs to be stalled with hesitant people reforms and procedural reforms.

Other important element of the regulation on the academic research reaches the interaction between the professor and his pupil, which takes place within the educational institutions, considered as the Ideological State Apparatuses, ISA (Althusser, 1999). The infrastructure of ISA enables and determine actions in Academy and for this reason we can state that this kind of work is regulated in order to ensure the universities accomplish government targets, evaluating things, regulating class relations. According to Kolsaker $(2008$, p. 1), there is a need to think about academic work in terms of Power relations between State, universities and academic staff. The academic professionalism was introduced in higher education in the form of a range of discourses and practices and there is evidence of an increasingly directive and prescriptive program that requires documents defining outcomes of teaching and learning.

Although the research activity in Academies and Research Institutes is based on the principle of research autonomy of, and on the individual originality in discovering new frontiers thus looking alike a subjective, introspective work, the research work is grounded on some more rigid objective schemes. The regulatory characteristic of academic activities indicates that these actions are under the rule of law in the sense the government demands certain action, and, on the other hand, they are under the protection of the law interfering in the academic work content.

The very specificity of law protection has to do with human rights, with intrinsic human condition, giving expression to a fundamental ethical basis: full and effective exercise of academic tasks in which dignity is recognized. In other words, academic success depends on the quality of administrative management, on its transparency and accountability, and in the respect for human rights.

"Over the last few decades, human rights have ceased to be a "fringe activity", instead becoming an area of law which is fundamen- 
tal to everyone and which permeates all legal activity, economic and social, in public law and in private" (Goldsmith; Cowdery, 1999, p. 1). The authors stated that human rights permeate the activities in society. We emphasize that human rights must permeate the academic work, for we are aware of the existence of situations in which once a traty has entered into force and is biding between an educational institution and a Professor, the first one must fulfill the obligations of the treaty in good faith (pacta sunt servanda). This implies that the institution cannot avoid invoking the provisions of its internal laws to justify its inability to obligations. The educational institutions, in accordance with the principles of human rights (NESRI, 2019) are responsible for violations of their obligations, even when they were not intentional. In case of derogation of the treaty with an academic professional, "[...] the right to derogate must be construed so as not to sap the individual rights of their substance" (OHCHR, 2019, p. 17). This is the way to make human rights a living reality. Human rights are based on the search for human dignity and its principles lead us to see beyond compliance with the law, allowing us to verify whether the imposition of the regulations, although legal, fulfills the objective of giving human dignity to a professor for instance.

Another issue that is come up the lack of observance of the principles that govern human rights, disfiguring the dignity, is the case of the unethical policy of the publishers who charge authors for the publication and then obtain money from the University where the same author works, in case some researcher wants to have access to this document. Another politically incorrect situation to which the researcher is subjected in his work is the metric-bibliographic system for the evaluation of the academic activity based on $\mathrm{H}$-index, scopus, generating the monopolistic influence of scientific journals of renown in the research, that publish under the conflict of interest of one of them by the high level of their journals, which is evaluated by an index that belongs to the other Scientific journal linked to the first one.

\section{Trust and Dignity in the Research Activity}

Although in academic relationship "[...] academics recognise no boss, choosing to see themselves as individual entrepreneurs" (Dearlove, 2002, p. 267), it is important to emphasize that the mentoring process is based on State regulations and on trust.

Trust one encompasses a very high complex form of relationship with particular dynamics and contextual contingencies in the Psychological context as we can see in the following citations.

\footnotetext{
Interpersonal trust is defined as the perception you have that other people will not do anything that will harm your interest; the individual is giving the willingness to accept vulnerability or risk based on expectations regarding another person's behavior (Williams, 2018, p. 3).
} 
Qualitative Analysis on the Academic Work

People trust others based on assumptions that these others will behave in a certain way [...] and that this will provide them with an expected desirable outcome [...]. Despite interdisciplinary differences most scholars agree that trust is essentially a psychological state that manifests itself in the behavior toward others [...]. As a psychological state, trust comprises positive expectations and the willingness to become vulnerable to the actions of others [...]. Positive expectations refer to the belief in the trustee(s): (a) ability or competence on various performance dimensions, (b) benevolence or goodwill toward the trustor, and (c) integrity or the willingness to fulfill the commitments to trustors [...]. This suggests that trust essentially comprises an individual and a relational component, respectively, regarding the characteristics of the trustor and of the trustee(s) and regarding the relationship between trustor and trustee(s) [...]. The willingness to become vulnerable to the actions of others associates trust with the risk that the behaviors of others can do you harm. [...] trust as the expectation that another's action" will be beneficial rather than detrimental" [...]. This suggests also that trust is related to risk taking, in the sense that, by trusting, the trustor expects that the desirable outcome will materialize, in spite of the possibility of being disappointed [...] (Costa; Frankhema, 2018, p. 4-5).

In the managerialism trust has normative aspects, wich means that it becomes protected by Law.

After several decades of scholarly focus on control as governance mechanism, trust has become increasingly recognized as a central mechanism in the coordination of expectations, interactions, and behaviors within organizational relations (Costa; Frankhema, 2018, p. 2).

"Trust provides incentives for cooperation, reduces uncertainty, and increases information exchange" (Costa; Frankhema, 2018, p. 7). Trust definitions vary and have been inherently elusive challenging scholars due its possibility to be harmful and to lead to betrayal. When trust involves mentoring process in the University (as an Ideological State Apparatuses, ISA) (Althusser, 1999), betrayal gets characteristics of Intellectual Property matters, due to the formal control of mentoring process.

Commercial exploitation of academic ideas is a recent phenomenon. The legal regulation of academic work is an important precondition to make trust effect more predictable (Luhmann, 1979; Zucker, 1986) and to protect trust's fragile governance mechanism in situations of continuous change (Costa; Frankema, 2018, p. 8). Trust has a characteristic-based model tied to person, to social elements, that intereferes on institutional trust-producing structures, on bureaucratic organizations, on professional credentialing, on regulation and on legislation, according to Zucher (1986). 


\section{Creativity and Academic Mentoring}

The functioning of the State is based on the belief that there is a common good superior to the interests of all to be preserved, and it is in relation to the pursuit of this common good that the notions of general interest, rights and duties of the citizen, are present in legal doctrine. The norms impose a must-be which contains pre-existing repression of the obligation by equating it with an imperative and an instrument of measurement (Monte-Serrat, 2013, p. 35).

The mentoring process is governed by rules, but they do not contemplate some intrinsic aspects that we highlight in our analysis and that we understand that interfere in the result of the academic work for it is assumed that language is a form of being in the world and that through it the individual constructs his identity. It is through the narrative that perception and desire are said (Ricoeur, 1986). Personal identity, before being transformed into narrative identity, is linked to the fact of telling something to someone, because there is a reflexivity in telling. It is in this way we analyse the mentoring process.

According to Ricoeur (1980, p. 776-777; Wong, 2019, p. 50), language has two dimensions: the somatic and the cognitive. In order to say something, one demands the sensitive dimension of the experience of the body (Merleau-Ponty, 1964, p. 306). Each of these dimensions of language will interfere with the constitution of meaning: somatic experience is the experience of the body with respect to reality; cognitive experience transforms this experience of reality into concepts (MerleauPonty, 1945, p. 231).

Husserl ([1929] 1992, p. 242), in his turn, affirms that discourse meaning (logos) relies on the experience of the body (phusis). Meaning can not be reduced to the capacity of thinking; it is constructed in the articulation between cognitive predicates and somatic predicates (which involve articulation to the participation of the body, the gesture, the voice). The construction of the sense of something provokes a resonance of our body with other bodies and with the world (Merleau-Ponty, 1995, 271).

According to what has been previously stated, it can be concluded that mentoring process involves logos and phusis. In order for one to be able to classify something from the cognitive perspective, he/she must first go through the somatic predicates, that is, through experimenting things and experiencing the other's participation. While the student does not acquire experience in the researched subject, this experience is transmitted to him by the research guider. The student's cognitive instance is linked to a generalizing perception. For his perception to become unique and creative (not generalized), it must pass through the somatic predicate (body, gesture, voice of someone). This last perception has boundaries that are undefined and unrepeatable and constitutes a creative perception, a somatic experience which transcribes reality by interpreting, deciphering the senses. 
Qualitative Analysis on the Academic Work

The use of somatic dimension, offered by the mentor in an academic work, makes the conditions of analysis different on different occasions. This makes the transmission of knowledge an authorial work in its essence. The transmission of experience is established in the order of the body and, therefore, it is not carried out at a distance, because it is not a cognitive task.

The transmission of human experience is inherent to the body and the knowledge (message) transmission occurs between two bodies (Benveniste 1974, p. 68). This process involves identification, empathy (passion in sharing), since the somatic dimension (feeling) overlaps with the cognitive dimension (vision).

The creative process is taken as an existential process in which there is a point of intersection at the level of the manifestation of feelings or ideas of the subject, in which memory and sensations depend on an operant and actual body. It is the body that builds and manifests meaning. There is an intersection that does not show the limits of different scales of space projects. Creating is an existential process. It does not just encompass thoughts or emotions. The experience and ability to shape and discern symbols and meanings originate in deeper regions of our inner world where the intellect structures the emotions. They are continuous and integral levels in which currents flow between conscious and unconscious and where from early in our life the modes of perception itself are formulated that will form a unity, a mixture of objective and subjective, in which the whole is prior to the parts; forms an undivided unity, which surpasses the differentiation between the subjective and the objective, integrating these parts.

Regarding to lack of trust in mentoring process, Intellectual Property matters not because it has potential commercial purpose, but because new ideas emerge from the authorship and, in this case, copyright must be assured.

The main forms of intellectual property in academic work are copyright and patents. Under United Kingdom legislation, copyright in an original literary, musical or other work is owned by its author(s), and the right to patent an invention is reserved primarily to its inventor(s) (CDPA, 1977).

Authorship and intellectual property are creations of the mind, inventions, and are protected because of the need for people to be recognized, to avoid misappropriation or to gain financial benefit from their inventions or creations (Chaves, 2018, p. 44-45).

Legal information on intellectual property (IP), such as treaties, IP-related treaties, laws and regulations is vast. Some of them can be found in the Official Journal of the European Union, OJEU (2014). In this paper we take the Directive 2014/26/EU of the European Parliament (2014) and of the Council of $26^{\text {th }}$ of February 2014, as an example due to the fact that it reaches many countries at the same time. It has, as content, a collective management of copyright and related rights and multi- 
territorial licensing of rights (OJEU, 2014; European Parliament, 2019). Those directives contribute to develop creativity, to protect innovation and intellectual creation. They intend to monitor the use of rights and the enforcement of copyright and related rights to enable the rightholders to be remunerated for uses of their idea. This legal protection is necessary because of the problems with the functioning of protection lead to inefficiencies in the exploitation of copyright.

There is an important principle here on arrangements concerning the management of rights: the text (OJEU, 2014) mentions an agreement between the author of the idea and the user. This does not affect the possibility, by regulation or by a specific mechanism, to rightholder get fair compensation for exceptions or limitations to the right reproduction. Laws prescribe the rights and the categories of rights to maintain a balance between the freedom of the rightsholders to dispose of their works and the transfer all or part of them to another person.

The aim of protection of intellectual property is to provide, generally speaking, efficient and impartial prescriptions of procedures to organize the use of ideas between their author and users based on proposed conditions or on a contract in order to avoid conflicts or misappropriation. States should establish appropriate procedures and competent authorities to ensure the application of regulatory directives on this subject. The imposition of sanctions or measures by national laws should contain specific sanctions and measures that have the capacity to dissuade someone from misappropriating the idea of another, like dismiss the person who acted negligently or, in cases an authorisation was issued, the withdraw of such authorization (OJEU, 2014). In case of a multi-territorial conflict, it is suggested that States use an exchange of information to facilitate the monitoring.

A qualitative analysis of the academic work that follow an orientation, therefore, considers the socio-historical context in which there is a continuation of the transmission of guider's knowledge, since its content integrates the orientation as described above. In this way, academic teaching and research ought to be treated as academic copyright due to the mentor's lessons with authorship and whose intellectual property rights have to be considered. Law must regulate the situation in which the student work could only be contemplated as new research if there had been a break with everything that had been transmitted to him over the years. This break implies a destruction of the structure created during the mentoring period; a non-integration with what was taught to him; a non-access to what was transmitted to him. Otherwise, there is misappropriation of ideas of the academic mentor.

\section{The Breach of Trust: the reverse shameful stockholm syndrome, rs3}

After we have covered topics on the regulations that characterize the academic life and on the role of trust and dignity in its ethical di- 
Qualitative Analysis on the Academic Work

mension, we will now turn to an example of the interaction between the mentor and his pupil focusing on the breach of trust to explain a new concept: The Reverse Shameful Stockholm Syndrome, RS3.

Regarding to the relationship between the Professor and student, it is thoroughly disciplined by educational institutions. Our concern in this article is to emphasize the truth as an important element imprinting its mark on the scientific works. Obstacles to truth sometimes provoke what we label R2S3 to stand for Research Reverse Shameful Stockholm Syndrome. Let us remind that the Stockholm Syndrom is the emphatic aptitude of hostages toward captors, as shown by the hostages of a bank robbery in Stockholm in 1973. This propensity can be often seen in the interaction between two parties (two individuals), in particular when one of the parties suffers from the restrictions imposed by the other part. The Stockholm Syndrom can be also noticed in the relationship between abstract entities like the interdependence of individuals-media, individuals-social media, or state-state, state-state organizations. For instance, the growing disaffection of Europeans against the European Union, and the increasing number of movements out of the official political schemes can be partially explained with the RS3. The Reverse Shameful Stockholm Syndrome appears when one party is ceasing any relationship with the other and behave against the other.

Although media uses it a lot, there has not been a lot of professional research into the phenomenon of Stockolm Syndrome. After reading some articles on this topic we found contradictions on what this is definitely and little published papers on it.

Consisting of strong emotional ties developed between two persons allied, as a survival strategy during captivity, Stockholm syndrome gives rise to a feeling considered irrational, paradoxical (Cantor; Price, 2007), as a result from a bond formed between captor and captives during intimate time spent together. It is considered a contested illness (Adorjan et al., 2012) and extrapolates kidnapping situations to describe reactions of sexual abuse, human trafficking, discrimination, terror, political oppression. The basis upon which scientific work is built allows it to be added to this list and is conceived under the new concept of the Reverse Shameful Stockholm Syndrome, RS3.

The situation in which there is a Professor to whom a student is subordinated and with whom this person learns to take the first steps on Academy gives opportunity to the pupil develop positive feelings toward his superior and sympathy for his causes and goals. This involves physical, emotional, cognitive and social effects evaluated as positive, in order to instigate the students to develop curiosity and to deepen their scientific knowledge.

According to Rotenberg and others (2005) interpersonal trust has three fundamental bases: reliability (fulfillment of word or promise); emotional (reliance on others to prevent emotional harm); and honesty (telling the truth and engaging behaviors guided by benign intent rather than manipulative strategies). The author (Rotenberg, 2005) states 
that behavioral domain has to do with individual behavioral tendencies to rely on others to act reliably, in an emotional and honestly fashion.

Costa and Frankema (2018) state that trust makes control mechanisms more effective, brings harmony to the relationship. On the other hand, the authors say that with lack of trust it will be "[...] difficult to accept control in relation to outcome measurements, to follow specified behavior patterns or to share values". Williams adds that distrust is a negative expectation regarding another's conduct wich leads to mistrust, fear, vigilance or suspicion. Distrust thus derives from the negative partner's behavior (Williams, 2018, p. 5)

In case the confidence between mentor and student is broken, RS3 can be configured. We propose this new brand for the reverse behavior that has nothing to do with distrust as a necessary component of rational assessment. We are talking about the Reverse of Shameful Stockolm Syndrome (Anti-Syndrome), RS3. It is a logical reverse phenomenon of specialized cases, in which a bad and ungrateful human trait, focused on a negative, dysfunctional or even unethical action, is fired against researchers who supported the betrayer and who helped him his first steps, involving paradoxically a negative relationship with tutor that may persist beyond the end of mentoring time.

Anxiety and fear, usually associated with the idea of survival, function as a defense disorder that works on maximum alert in threat situations (Cantor; Price, 2007). This defense disorder, in RS3, is improperly established in the mentoring situation, that is, where there should be a conscious and voluntary choice of appeasement in a submission relation-be it genuine or simulated choice-, a paradoxical situation arises in that the student ceases to be submissive and feeds feelings of revenge or rebellion. This ingratitude is usually committed by a student who has barely begun to smell any force. In this situation, if there is no remedy after the attempts, it is best to leave him helpless and de-functionalise this product and keep him in a state of sleep. Or we can try to find a way to escape this fate.

\section{Conclusion}

The present article has provided a qualitative analysis of the academic work under the impact that the principles of dignity and truth have upon it in a world's yearning for respect, security and justice in the research work. It describes intrinsic aspects that put creativity as its essential product, and contextual (extrinsic) aspects necessary to establish trust and dignity as necessary assumptions to achieve its goal. These elements were described separately for didactic purposes but should be understood as interdependent. The content of this article is a tool available to protect creativity against abuses of power. It emphasizes the fact that the ethical dimension of scientific work is a prerequisite for the emergence of creativity and that the breakdown of this dimension can occur in two aspects: Intrinsic, as a result of ungratefulness, 
Qualitative Analysis on the Academic Work

generally committed by a student, installing RS3, or extrinsic, which transforms academic work into a commercial product, repetitive, without creation, making it a fallacy.

Received on February $3^{\text {rd }}, 2019$

Approved on April 22 ${ }^{\text {th }}, 2019$

\section{References}

ADORJAN, Michael; CHRISTENSEN, Tony; KELLY, Benjamin; PAWLUCH, Dorothy. Stockholm Syndrome as Vernacular Resource. The Sociological Quarterly, London, v. 53, n. 3, p. 454-74, 2012.

ALTHUSSER, Louis. Ideologia e Aparelhos Ideológicos do Estado. In: ZIZEK, Slavoj (Org.). Um Mapa da Ideologia. Rio de Janeiro: Contraponto, 1999. P. 105142.

BENVENISTE, Emile. Problèmes de Linguistique Générale. Paris: Gallimard, 1974.

CANTOR, Chris; PRICE, John. Traumatic Entrapment, Appeasement and Complex Pos-Traumaitc Stress Disorder: evolutionary perspectives of hostage reactions, domestic abuse and Stockholm syndrome. Australian and New Zealand Journal of Psychiatry, Sydney, p. 377-384, 2007.

CDPA. Copyright, Designs and Patents. ACT 1988 s. 11(1) Patents Act 1977. Legislation of the United Kingdom Government. London, 1977. Retrieved from: <https://www.copyrightservice.co.uk/copyright/uk_law_summary>. Access on: $3^{\text {rd }}$ of February, 2019.

CHAVES, Marcelo. Proteger ou Não Proteger: a proteção da propriedade intelectual dos conteúdos criados por inteligência artificial. In: PINHEIRO, Patricia Peck (Org.). Direito Digital Aplicado 3.0. SãoPaulo: Thomson Reuters Brasil, 2018.

COSTA, Ana Cristina; FRANKEMA, Katinha. Trust and Control Interrelations: new perspectives on the Trust-Control Nexus, Faculty of Technology, Policy and Management at the Delft University of Technology in the Netherlands and Department of Public Administration and Organization Sciences at the Free University Amsterdam, First International Network on Trust (FINT). No date. Retrieved from: <https://pdfs.semanticscholar.org/91f5/6778cb854594b5c0c24 $3 c 574 b 8 c 1289738 d 0 . p d f>$. Access on: $25^{\text {th }}$ of June, 2018.

DEARLOVE, John. A Continuing Role for Academics: the governance of UK universities in the post-Dearing era. Higher Education Quarterly, Baltimore, v. 56, n. 3, p. 257-275, 2002.

EUROPEAN PARLIAMENT. Copyright in the Digital Single Market, 26 March, 2019. 2019. Retrieved from: <http://www.europarl.europa.eu/doceo/document/TA-8-2019-0231_EN.html>. Access on: Mai, 16 $6^{\text {th }}, 2019$.

EUROPEAN PARLIAMENT. Directive 2014/26/EU of the European Parliament and of the Council of 26 February 2014 on collective management of copyright and related rights and multi-territorial licensing of rights in musical works for online use in the internal market. 2014. Retrieved from: <https://eur-lex.europa.eu/legal-content/EN/TXT/?uri=celex\%3A32014L0026>. Accessed on: $16^{\text {th }}$ of May 2019.

FOUCAULT, Michel. The Archaeology of Knowledge. Translation by A. M. Sheridan Smith. London; New York: Routledge, 2002. [1969]. 
Belgacem; Monte-Serrat; Cattani; Cabella

GASQUET, Joachin. Encre Marine. France: La Versanne, 2002.

GOLDSMITH, Lord; COWDERY, Nicholas. The Role of the Lawyer in Human Rights. HRI News, London, v. 4, n. 2, p. 1, 1999.

HUSSERL, Edmond. Méditations Cartesiennes. Paris: Kluwer, 1992. [1929].

KOLSAKER, Ailsa. Academic Professionalism in the Managerialist Era: a study of English universities. Studies in Higher Education, London, v. 33, n. 5, 2008. Retrieved from: <https://srhe.tandfonline.com/doi/full/10.1080/030750708023 72885 ? scroll=top $\&$ needAccess $=$ true $\#$.WuTADy7wbIU>. Access on: $28^{\text {th }}$ of April, 2018 .

LUHMAN, Niklas. Familiarity, Confidence and Trust. In: GAMBETTA, Diego (Org.). Trust Making and Breaking Co-operative Relations. Oxford: Blackwell, 1998. P. 94-108.

MERLEAU-PONTY, Maurice. Phénoménologie de la Perception. Paris: Gallimard, 1945.

MERLEAU-PONTY, Maurice. Le Visible e l'Invisible. Paris: Gallimard, 1964

MONTE-SERRAT, Dionéia. Letramento e Discurso Jurídico. 2013. Thesis (Doctorate in Psychology) - Faculdade de Filosofia, Ciências e Letras de Ribeirão Preto, Universidade de São Paulo, FFCLRP-USP, 2013. Retrieved from: <http:// www.teses.usp.br/teses/disponiveis/59/59137/tde-14032013-104350/pt-br. php>. Access on: $16^{\text {th }}$ of May, 2019.

NESRI. National Economic \& Social Rights Initiative. What are the Basic Principles of the Human Rights Framework? 2019. Retrieved from: <https://www. nesri.org/programs/what-are-the-basic-principles-of-the-human-rightsframework $>$. Access on: January $9^{\text {th }}, 2019$

OHCHR. Office of the United Nations High Commissioner for Human Rights. International Human Rights Law and the Role of the Legal Professions. Geneva: OHCHR, 2019. Retrieved from: <https://www.ohchr.org/documents/publications/training9chapterlen.pdf $>$. Access on: January $9^{\text {th }}, 2019$.

OJEU. Official Journal of the European Union. Directive 2014/26/Eu of the European Parliament and of the Council of 26 February 2014 on collective management of copyright and related rights and multi-territorial licensing of rights in musical works for online use in the internal market. OJEU, online, L. 84/72, 2014. Retrieved from: <http://www.wipo.int/wipolex/en/text.jsp?file_id=332724>. Access on: $24^{\text {th }}$ of June, 2018.

PÊCHEUX, Michel. Semântica e Discurso: uma crítica à afirmação do óbvio. Campinas: Unicamp, 1988.

RICOEUR, Paul. Philosophies du Langage. Encyclopedia Universalis, Paris, p. 776-777, 1980.

RICOEUR, Paul. Du texte à l'action. Essais dlierméneutique II. Paris: Seuil, 1986.

ROTEMBERG, Ken; FOX, Claire; GREEN, Sarah; RUDERMAN, Louise; SLATER, Kevin Stevens. Construction and Validation of a Children's Interpersonal Trust Belief Scale. British Journal of Developmental Psychology, London, v. 23, n. 2, p. 271-292, 2005.

WILLIAMS, Tiara. The Psychology of Interpersonal Trust: how people feel when it comes to trusting someone. Lebanon: McKendree University, no date. Retrieved from: <https://www.mckendree.edu/academics/scholars/issue22/ tiara-williams.pdf $>$. Access on: $28^{\text {th }}$ of April, 2018.

Educação \& Realidade, Porto Alegre, v. 44, n. 4, e90059, 2019. 
Qualitative Analysis on the Academic Work

WONG, Michael. Ricoeur and the Third Discourse of the Person: from the philosophy and neuroscience to psychiatry and theology. Nova York: Lexington Books, 2019

ZUCKER, Lynne. Production of Trust: institutional sources of economic structure. In: STAW, Barry (Org.). Research in Organizational Behavior. Greenwich: JAI, 1986. P. 53-112.

Fethi Bin Muhammad Belgacem is a Public Authority for Applied Education and Training, PAAET, Kuwait City, Kuwait Bachelor and Ph.D. in Biomedical Engineering. Degree in Mathematics and Engineering, University of Miami, USA. Faculty Member at the Department of Mathematics ORCID: https://orcid.org/0000-0003-0228-7829

E-mail: fbmbelgacem@gmail.com

Dionéia Motta Monte-Serrat is a Lawyer and Faculty member (Assistant Professor at undergraduation in Law) at Ribeirão Preto University (UNAERP) since 2013. Collaborating researcher at IEL-UNICAMP (Post Doc, 2014-2016). Doctoral degree in Psychology, FFCLRP-USP (2013). Doctoral degree program partly completed at Université Paris III, Sorbonne Nouvelle (2010, CAPES-BEX).

ORCID: http://orcid.org/0000-0002-4266-8979

E-mail: di_motta61@yahoo.com.br

Carlo Cattani is a Professor at the Department of Economics, Engineering, Society and Business Organization, DEIM, at Tuscia University, Italy. Top Italian Scientist for Mathematics, 2019. Adjunct Professor Ton Duc Thang University-HCMC, Vietanm. Editor in Chief of the Journal Fractal \& Fractional.

ORCID: https://orcid.org/0000-0002-7504-0424

E-mail: cattani@unitus.it

Daniela Monte-Serrat Cabella is a Data Protection Counsel at Neoway. Certified Data Protection Officer (DPO) by Exin. Specialized in Innovation Management and Digital Law. Post-graduated in Innovation Management and Digital Law, FIA. Bachelor of Laws, University of Sao Paulo. Member of the Brazilian Bar Association and of the International Association of Privacy Professionals (IAPP).

ORCID: https://orcid.org/0000-0002-3060-8733

E-mail: danielacabella@pgadvogados.com.br

This is an open-access article distributed under the terms of the Creative Commons Attribution License 4.0 International. Available at: <http://creativecommons.org/licenses/by/4.0>. 